\title{
Biometry of stomata in Blechnum species (Blechnaceae) with some taxonomic and ecological implications for the ferns
}

\author{
José María Gabriel y Galán ${ }^{1}$, Carmen Prada ${ }^{1}$, Cristina H. Rolleri ${ }^{2}$, Rafael Lahoz-Beltrá ${ }^{3}$ \& \\ Cristina Martínez-Calvo ${ }^{3}$ \\ 1. Departamento de Biología Vegetal I, Facultad de Ciencias Biológicas, Universidad Complutense de Madrid. Avda. \\ José Antonio Nováis, 2; 28040, Madrid, España; jmgabriel@bio.ucm.es; cpm@bio.ucm.es \\ 2. Laboratorio de Estudios de Anatomía Vegetal Evolutiva y Sistemática (LEAVES), Facultad de Ciencias Naturales \\ y Museo de La Plata, 64 entre 120 y diagonal 113, B1904 DZB, La Plata, Argentina. Consejo Nacional de \\ Investigaciones Científicas y Técnicas (CONICET); tinar@speedy.com.ar \\ 3. Departamento de Matemática Aplicada (Biomatemática), Facultad de Ciencias Biológicas, Universidad Complutense \\ de Madrid. Avda. José Antonio Nováis, 2; 28040, Madrid, España; lahozraf@bio.ucm.es; ccalvo@bio.ucm.es
}

Received 12-IV-2010. Corrected 10-IX-2010. Accepted 15-X-2010.

\begin{abstract}
Morphological stomatal traits, such as size, form and frequency, have been subject of much literature, including their relationships with environmental factors. However, little effort have focused on ferns, and very few in the genus Blechnum. Stomatal length, width and frequency (as stomatal index) of a number of specimens of fourteen Neotropical species of Blechnum were measured in adult pinnae. The aim of the work was to find biometrical relationships between stomatal traits and between stomatal traits and habit, habitat and ecosystem of the plants. Statistical analyses of data were conducted using Exploratory Data Analysis and Multivariate Statistical Methods. Stomatal length and width showed a very high correlation, suggesting an endogenous, genetic control, thus giving these traits a considerable diagnostic utility. With respect to the relationships between stomatal traits and environment, we found significant statistical relationships between altitude and stomatal index. We also addressed the interpretation of the ecological-selective significance of various assemblages of stomatal traits in a diverse conjunction of habits, habitats and ecosystems. Rev. Biol. Trop. 59 (1): 403-415. Epub 2011 March 01.
\end{abstract}

Key words: Blechnum, ferns, autoecology, selection, stomatal frequency, stomatal size.

Vascular plants can modify much of their bodies in order to better adapt themselves to the environment. In this sense, stomata appear to be of huge importance, as they control both photosynthetic and water plant relationships. Thus, from an ecological perspective, the knowledge of the stomata architecture and function is a critical matter to understand the fitness of plants to their environment. In addition, many efforts have been done to give stomata a taxonomic significance.

Stomatal morphology is quite well known in angiosperms and gymnosperms (cf. comprehensive syntheses by Metcalfe \& Chalk 1979,
Evert \& Eichhorn 2006) and also there is a well developed corpus on physiological and ecophysiological aspects (Haberlandt 1965, Sculthorpe 1971, Meidner \& Mansfield 1968, Jones 1998, Körner 1988, Salas et al. 2001, Bergmann 2003, Hetherington \& Woodward 2003, Öpik \& Rolfe 2005). Finally, the use of stomata in the taxonomy of these groups is also ample (cf. the syntheses by Baranova 1987, Prabhakar 2003). Unlikely, research on fern stomata morphology is actually scarce (Inamdar et al. 1971, Rolleri et al. 1987, Rolleri et al. 1994, Rolleri \& Lavalle 1997, Rolleri et al. 2003, Rolleri 2004). More deep gaps could be found 
when dealing with the physiology and ecophysiology of ferns (Hunt et al. 2002, Saldaña et al. 2005, Watkins et al. 2007a, 2007b), and also with the taxonomic use of stomata (Kondo \& Toda 1956, Thurston 1969, Fryns-Claessens \& van Cotthem 1973, van Cotthem 1973).

During the last years, strong evidence is accumulating towards the fact that fern stomata are and operate in a quite different way than those of gymnosperms and angiosperms: they have sometimes different morphology (Rolleri et al. 1994, Rolleri 2004), they close in a different way due to a different morphology (Franks \& Farquhar 2007), they show different physiological behavior to some light signals (Doi et al. 2006) and also they have different mediators in the stomata-controlling signals (Kawai et al. 2003).

Faced with these circumstances, it is clear that more studies are needed in ferns to translate all this morphological and physiological stomatal evidence to an auto-ecological scenario. From a morphological view, recent investigation on how the stomatal architecture of ferns is related with the external conditions is very scarce (Kessler et al. 2007, Kluge \& Kessler 2007), but is of high interest to understand the adaptive fitness of ferns to their environment.

This work investigates the biometrical relationships between certain stomatal traits of ferns, as length, width and frequency. The objectives are to understand how is the architecture of the stomata, to discover if the ferns stomata follow some of the generally accepted rules for angiosperms stomata, and to determine which is the nature and significance of its biometrical variability.

Afterward, we examine how these stomatal morphological traits change within a set of environmental situations, represented by the habit and habitat of plants -as general morphological responses to the environment-, and the ecosystems they inhabit. The objective is to discover general patterns on the relationship between morphology and environment in ferns.

We selected the fern genus Blechnum for the following two reasons: first, it comprises numerous species of different morphological and ecological scope breadth (Kramer et al. 1990, Rolleri \& Prada 2006a), so it could be representative to build a general model of relationships between stomata architecture and environment in ferns; and second, there is a certain recent experimental background that can be used (Rolleri \& Prada 2006b, Gabriel y Galán et al. 2008, Prada et al. 2008, Rolleri et al. 2008).

\section{MATERIAL AND METHODS}

In this study, the following 14 species were selected: $B$. auratum (Fée) R.M. Tryon \& Stolze, B. brasiliense Desv., B. columbiense Hieron., B. fragile (Liebm.) C.V. Morton \& Lellinger, B. hastatum Kaulf., B. kunthianum C. Chr., B. loxense (Kunth) Hook. ex Salomon, B. magellanicum Mett., B. mochaenum G. Kunkel, B. penna-marina (Poir.) Kuhn, B. tabulare (Thunb.) Kuhn, B. serrulatum Rich., B. sprucei C. Chr. and B. stuebelii Hieron. Data of the dry herbarium material used from MA is listed in Table 1. Species identification was made based on the floras of Tryon \& Stolze (1993) and Moran (1995), recent catalogs (Rolleri \& Prada 2006a), and also by determinations of the authors after consulting the type material.

Four different individuals were selected from each species, except for $B$. magellanicum and $B$. tabulare (three individuals) and $B$. auratum and $B$. fragile (two individuals). For every individual we recorded the location, the habitat and the altitude. Voucher information is shown in Table 1. Four different adult medium pinnae from each individual were studied; when it was possible, pinnae came from different fronds. Pinnae were restored with aqueous 4:1 butyl cellosolve, and cleared with aqueous $6 \% \mathrm{NaOH}$. Hand-made peelings of epidermal abaxial surface were made, and stained with aqueous 1\% TBO (Gurr 1966). Four different fields from the medium area of each pinna were observed using a compound light microscope. The information comes from a total amount of 800 samples (were samples equals fields scouted).

The following data were obtained from each sample: a) average length and average 
TABLE 1

Source of biological material, with its adscription to ecosystem, habit and habitat

\begin{tabular}{|c|c|c|c|c|}
\hline Species & Ecosystem & Habit & Habitat & Material \\
\hline B. auratum & PAR & $\mathrm{ARB}$ & TER & $\begin{array}{l}\text { Costa Rica: Gabriel y Galán w/n, jan 2008, MA. Perú: Gabriel y } \\
\text { Galán w/n, apr 2008, MA. }\end{array}$ \\
\hline B. brasiliense & SA & ARB & PAL & Argentina: Prada w/n, sept 07, MA. \\
\hline B. columbiense & PAR & $\mathrm{ARB}$ & TER & $\begin{array}{l}\text { Colombia: Jaramillo \& van der Hammen 4399, nov 1967, MA; } \\
\text { Jaramillo \& van der Hammen 4287, nov 1967, MA; Murillo \& } \\
\text { Villareal 1370, jun 1970, MA; Cuatrecasas 2081, apr 1932, MA. }\end{array}$ \\
\hline B. fragile & $\mathrm{TF}$ & HER & EPI & Costa Rica: Gabriel y Galán w/n, jan 08, MA. \\
\hline B. hastatum & $\mathrm{CHF}$ & HER & TER & $\begin{array}{l}\text { Argentina: Prada A21, nov 05, MA; Prada A130, nov 06, MA. } \\
\text { Chile: Prada A103, nov 06, MA. }\end{array}$ \\
\hline B. kunthianum & TF & HER & EPI & Argentina: Prada w/n, sept 08, MA. \\
\hline B. loxense & PAR & ARB & TER & $\begin{array}{l}\text { Colombia: Jaramillo et al. 2784, aug 1967, MA. Ecuador: Holm- } \\
\text { Nielsen et al. 29614, dec 1980, MA. Perú: s. coll. 4270, jun } \\
\text { 1997, USM; Gabriel y Galán w/n, apr 08, MA. }\end{array}$ \\
\hline B. magellanicum & $\mathrm{CHF}$ & $\mathrm{ARB}$ & TER & $\begin{array}{l}\text { Chile: Neé w/n, w/d, MA; Pisano 5942, nov 1985, MA; Pisano } \\
\text { 6455, dec 1988, MA; Pisano 6573, dec 1988, MA. }\end{array}$ \\
\hline B. mochaenum & $\mathrm{TF}$ & HER & TER & $\begin{array}{l}\text { Argentina: Prada A34, nov 05, MA; Prada \& Gallardo w/n, jun } \\
\text { 07, MA. }\end{array}$ \\
\hline B. penna-marina & $\mathrm{CHF}$ & CAE & TER & Argentina: Prada A39, nov 05, MA; Prada A42, dec 05, MA. \\
\hline B. tabulare & SA & ARB & PAL & Uruguay: Prada w/n, jul 08, MA. \\
\hline B. serrulatum & SA & HER & PAL & Argentina: Prada \& Fuertes, jul 08; MA. \\
\hline B. sprucei & TF & HER & TER & Argentina: Prada \& Gallardo w/n., jun 07, MA. \\
\hline B. stuebelii & $\mathrm{TF}$ & HER & TER & Perú: Gabriel y Galán w/n, apr 08, MA. \\
\hline
\end{tabular}

Ecosystem: CHF Cold hyperhumid forest; SA Swampy areas; TF Tropical low and montane forest; PAR Páramo. Habit: ARB Arborescent; CAE Caespitose; HER Herbaceous. Habitat: PAL Amphibious; TER Terrestrial; EPI Epiphyte.

width of four randomly selected stomata, and b) number of stomata (NS) and number of epidermal cells (NE) in the area covered by a $20 x$ magnification lens. Elongate cells of epidermis over veins, and cells with half of the surface outside the observation field do not entered into the counting. Stomatal frequency was calculated as stomatal index (SI), as follows (Salisbury 1927): SI= (NS·100)/(NS+NE). Size is expressed in $\mu \mathrm{m}$.

Selection of plant habits and types of habitat/ecosystems was conducted using three sources of information: a) herbarium specimens from several herbaria, b) general fern literature (Kramer et al. 1990, Lellinger 2002), c) catalogs and floristic treatments of Blechnum (Tryon \& Tryon 1982, Tryon \& Stolze 1993, Moran 1995, Rodríguez 1995, Smith 1995, Ponce 1996, Mickel \& Smith 2004, Oliveira Dittrich 2005) and other recent works (Rolleri \& Prada 2006b, Gabriel y Galán et al. 2008, Prada et al. 2008, Rolleri et al. 2008).

The habits considered were caespitose, herbaceous and arborescent (including subarborescent). We considered as caespitose habit those plants growing in small tufts, as grasses, usually not rising more than a few centimeters from above the substrate. The plants with this 
habit often form extensive lawns, partially covering each other, usually living in lower latitudes or higher altitudes. Under herbaceous habit, we have include those plants having an epigeous (or subterranean) rhizome which bears erect fronds, ie., sporophytes rarely more than $100-120 \mathrm{~cm}$ high. It is obvious that the "herbaceous habit" also include nidiform, calathiform, rosulate, and scandent corms, but these forms are uncommon or not found in Blechnum. Arborescent habit means that the corm have the habit of a small "palm" tree, with an obvious caudex, and a crown of large fronds; we include here also sub-arborescent forms, since the length of the erect rhizome may vary from $60-120 \mathrm{~cm}$ and up to $2-3 \mathrm{~m}$. The habitats include terrestrial, amphibious and epiphytic. Ecosystems chosen were tropical low and montane rainforests, swampy and flooded areas, cold hyperhumid woods and paramos. Table 1 shows the adscription of each species to habit, habitat and ecosystem.

Statistical analysis of data was accomplished using the statistical package STATGRAPHICS 5.1 (Statistical Graphics Corporation). In order to analyze the data we applied an Exploratory Data Analysis and Multivariate Statistical Methods such as principal components analysis, biplot analysis and discriminant analysis (Tukey 1977, Rencher 1995).

\section{RESULTS}

Raw data can be obtained from Gabriel y Galán et al. (2010). There was a strong correlation between stomatal length and width when all data were combined (Fig. 1; WIDTH= 6.469 +0.544 LENGTH; $\mathrm{R}^{2}=0.655, p=0.000 ; \mathrm{df}: 1$, 798). Furthermore, regression ANOVA analysis between the stomatal index and stomatal length $\left(\mathrm{STOINDEX}=37.521-0.183\right.$ LENGTH; $\mathrm{R}^{2}=$ $0.0507, p=0.000$; df: 1,798$)$, and between the stomatal index and the stomatal width (STOINDEX $=44.018-0.457$ WIDTH $; R^{2}=0.1429$, $p=0.000$; df: 1,798 ) showed that there were statistically significant relationship between the stomatal index and length, and between the stomatal index and width. In this manner, the aforementioned linear relationships explained the $5.07 \%$ and the $14.297 \%$ of the stomatal index variability, respectively.

The length of the stomata was compared in the fourteen species of Blechnum (Fig. 2A), appearing significant differences in the variances (Cochran's C test, $p=5.804$ 10 $0^{-9}$; Bartlett test, $p=0.000)$ and among the medians at the $95.0 \%$ confidence level (Kruskal-Wallis test, $p=0.000$ ). We found the following groupings of species: a) $B$. brasiliense- $B$. serrulatum; b) $B$. tabulare$B$. magellanicum- $B$. loxense- $B$. columbiense- $B$. auratum; c) B. hastatum- $B$. sprucei-B. kunthianum; and d) B. mochaenum- $B$. fragile; whereas $B$. penna-marina and B. stuebelii appeared alone and were different from the rest of species. These two species showed the smallest and the longest stomata, respectively. For the stomatal length we found that $B$. kunthianum shows the greatest variance and $B$. penna-marina the smallest variance, which presumably could be related with selection pressure. The length of the stomata varied according to different habits (Fig. 2B), with significant differences among variances (Cochran's C test, $p=0.000$; Bartlett test, $p=0.000$ ) and among medians at the $95.0 \%$ confidence level (Kruskal-Wallis test, $p=0.000$ ). In consequence, arborescent and caespitose habits were statistically similar but different from the herbaceous. Similar results were obtained when we studied the variability of the stomatal length for a given habitat (Fig.

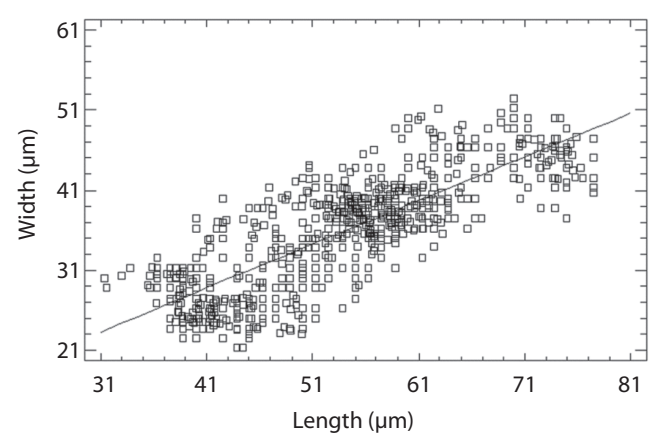

Fig. 1. Regression analysis between stomatal length and width (in $\mu \mathrm{m}$ ) in Blechnum. 
A

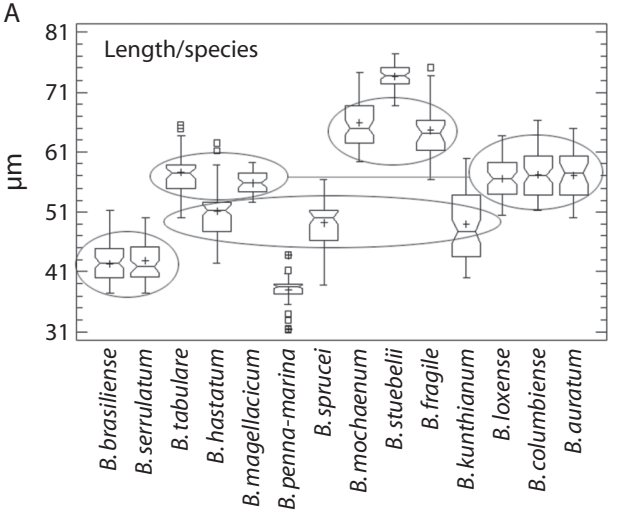

C

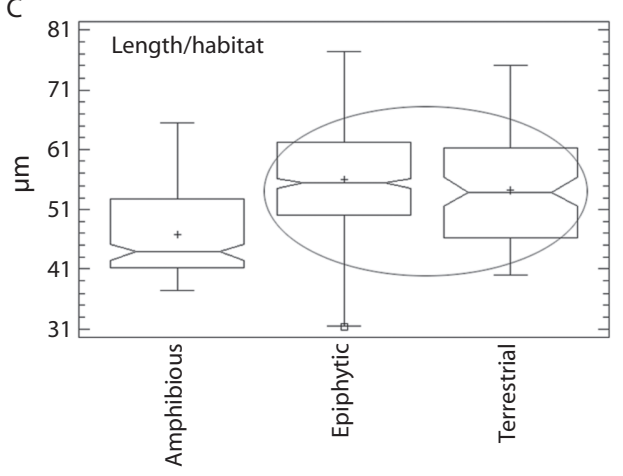

B

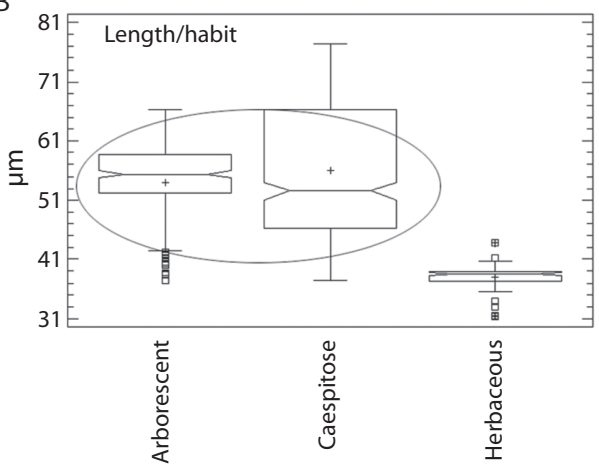

D

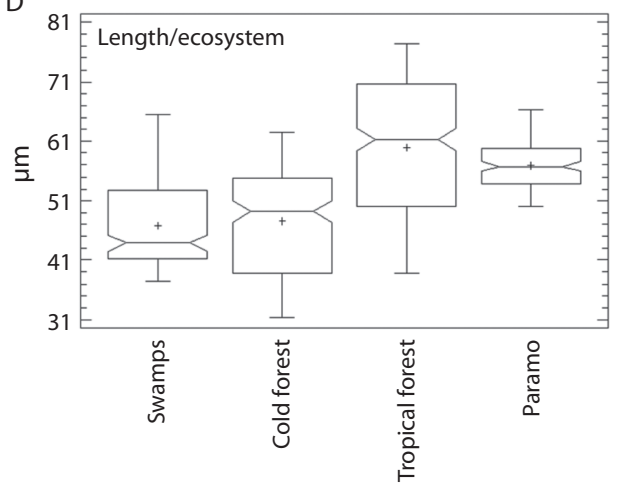

Fig. 2. Biometrical relationship between stomatal length (in $\mu \mathrm{m}$ ) and species (A), habits (B), habitats (C) and ecosystems (D) in Blechnum. Circles show the statistically significant groupings.

2C). Once again, tests showed significant differences among variances (Cochran's C test, $p=0.000$; Bartlett test, $p=0.000$ ) and among medians at the $95.0 \%$ confidence level (Kruskal-Wallis test, $p=0.000$ ). We found that terrestrial and epiphytic habitats were equal and statistically different from amphibious habitat. Finally, when we studied the variability of the stomatal length in different ecosystems (Fig. 2D) we found significant differences among variances (Cochran's C test, $p=0.000$; Bartlett test, $p=0.000$ ) and among medians at the 95.0\% confidence level (Kruskal-Wallis test, $p=0.000$ ). In consequence, we found significant differences in stomatal length among the four studied ecosystems, but no groupings could be done in this case.
The stomatal width was also compared in the fourteen species of Blechnum (Fig. 3), showing significant differences among variances (Cochran's C test, $p=9.316$ 10 $0^{-7}$; Bartlett test, $p=0.000)$ and among medians at the 95.0\% confidence level (Kruskal-Wallis test, $p=0.000$ ). We found the following groupings of species: a) $B$. brasiliense- $B$. serrulatum; b) $B$. tabulare- $B$. magellanicum- $B$. fragile$B$. loxense- $B$. kunthianum- $B$. columbiense- $B$. auratum; c) B. penna-marina-B. sprucei; and d) $B$. mochaenum- $B$. stuebelii; whereas $B$. hastatum appears alone and is different from the rest of species. B. mochaenum shows the widest stomata and $B$. brasiliense the narrowest ones. For the stomatal width we found that B. kunthianum presents the greatest variance 


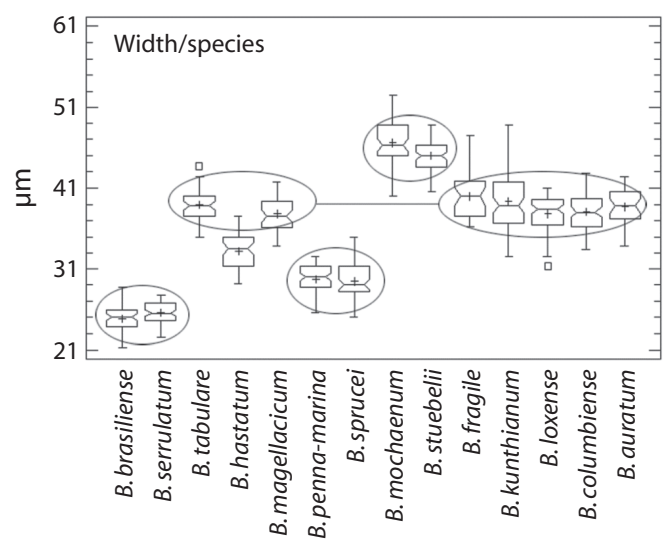

Fig. 3. Biometrical relationship between stomatal width (in $\mu \mathrm{m})$ and Blechnum species. Circles show the statistically significant groupings. and $B$. brasiliense the smallest variance. Once again, we conducted the same tests to study a possible effect of environment (habit, habitat and ecosystem) on stomatal width. In all the three tests, we found significant differences among variances (for all the cases, the Cochran's $\mathrm{C}$ test and the Bartlett test showed $p=0.000$ ), and among medians at the $95.0 \%$ confidence level (Kruskal-Wallis test, $p=0.000$ in all the cases). Thus, we found that for the stomatal width, the same groupings were obtained with the stomatal length.

A similar statistical analysis protocol was conducted with the stomatal index. The stomatal index was compared in the fourteen species of Blechnum (Fig. 4A), resulting in significant differences among variances (Cochran's $\mathrm{C}$ test, $p=0.000$; Bartlett test, $p=0.000$ ) and
A

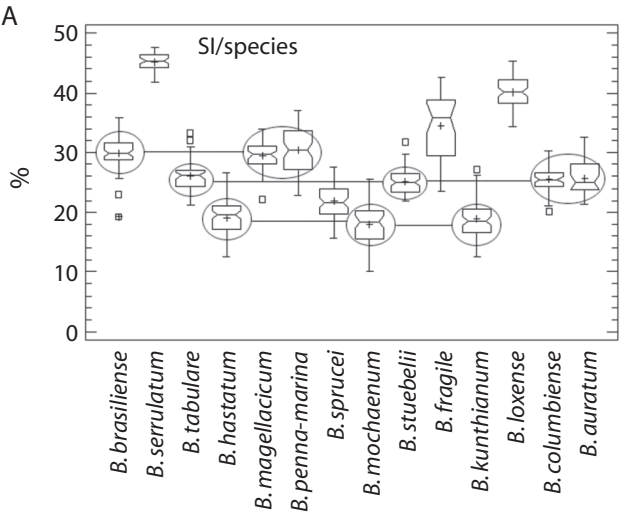

C

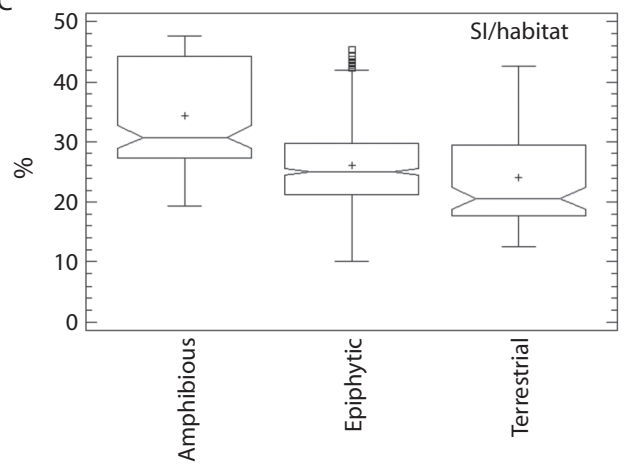

B

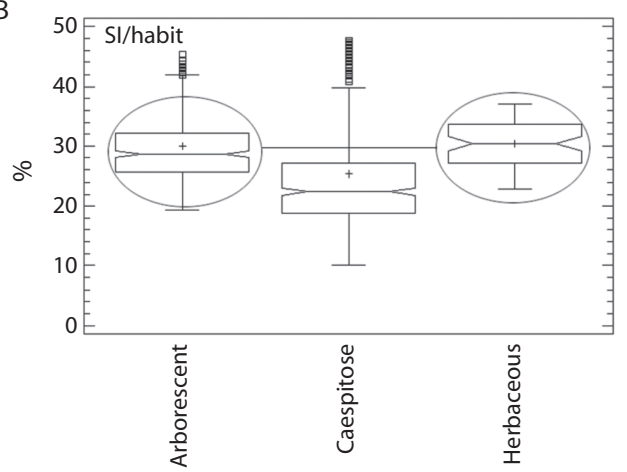

D

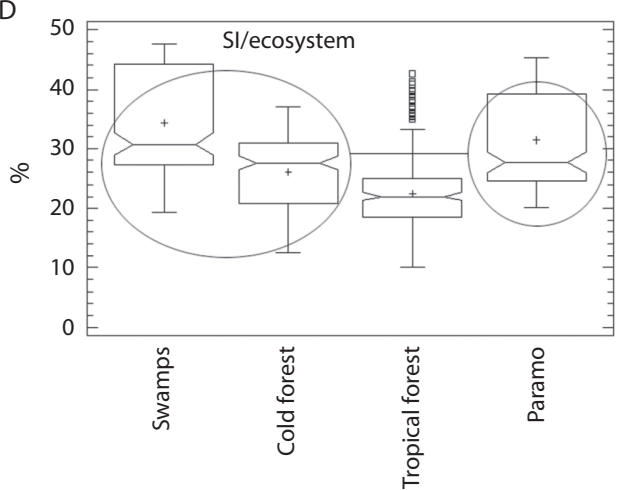

Fig. 4. Biometrical relationship between stomatal index (in \%) and species (A), habits (B), habitats (C) and ecosystems (D) in Blechnum. Circles show the statistically significant groupings. 
among medians at the $95.0 \%$ confidence level (Kruskal-Wallis test, $p=0.000$ ). We found the following groups of species: a) $B$. brasiliense- B. magellanicum- B. penna-marina; b) $B$. tabulare- B. stuebelii- B. columbiense- $B$. auratum; and c) B. hastatum- B. mochaenum- B. kunthianum. Blechnum serrulatum, B. fragile, B. loxense and B. sprucei didn't belong to any group. Blechnum serrulatum showed the highest stomatal index, whereas B. mochaenum and B. stuebelii had the lowest values. Blechnum fragile presented the highest stomatal index variability and $B$. serrulatum the lowest variability (which could be related with a high selection pressure). The stomatal index depends on habit (Fig. 4B). The variance tests showed significant differences among variances (Cochran's C test, $p=0.000$; Bartlett test, $p=0.000$ ) and also there were statistically significant differences among medians at the 95.0\% confidence level (Kruskal-Wallis test, $p=0.000)$. In consequence, arborescent and herbaceous habits were similar, but statistically different from the caespitose habit. Similarly, different habitats have an effect on stomatal index values (Fig. 4C). We found significant differences among variances (Cochran's C test, $p=0.1213$; Bartlett test, $p=0.0047$ ) and among medians at the $95.0 \%$ confidence level (Kruskal-Wallis test, $p=0.000$ ). Thus, considering the stomatal index, there were significant differences among the three habitats studied, but no groupings could be done in this case. Finally, when we studied the effect of different ecosystems on the stomatal index (Fig. 4D) we found significant differences among variances (Cochran's C test, $p=0.000$; Bartlett test, $p=$ 0.000 ) and among medians at the $95.0 \%$ confidence level (Kruskal-Wallis test, $p=0.000$ ). As a result, we found that stomatal index of individuals from swamps, cold hyperhumid woods, and paramo ecosystems were similar and statistically different from those of tropical forests.

In order to carry on a discriminant analysis the data were classified in the fourteen species of Blechnum. Considering the p-value the first, second and third discriminant functions were statistically significant. The first discriminant function accounted for $74.74 \%$ of the variance whereas the second for $20.70 \%$ of variance. We can state that the model was successfully discriminating among the fourteen species. Furthermore, we found that there was a high correlation between the first and second discriminant functions and the Blechnum species. The 2D scatter plot of the two functions (Fig. 5) showed that there were observations fairly clustered into species (i.e. B. serrulatum, B. hastatum, B. fragile). However, some overlapping was observed (i.e. $B$. brasiliense$B$. mochaenum, B. tabulare-B. columbienseB. sprucei, B. penna-marina-B. sprucei, $B$. serrulatum- $B$. hastatum). The classification table showed that $76.00 \%$ of the samples were correctly identified. It is noteworthy that when altitude was included in the discriminant analysis, the overlapping between or among species was significantly reduced, and the classification table reflected that $91.0 \%$ of the species were correctly identified.

We finally conducted a principal component analysis with the original data represented as a 4-dimensional composition of the

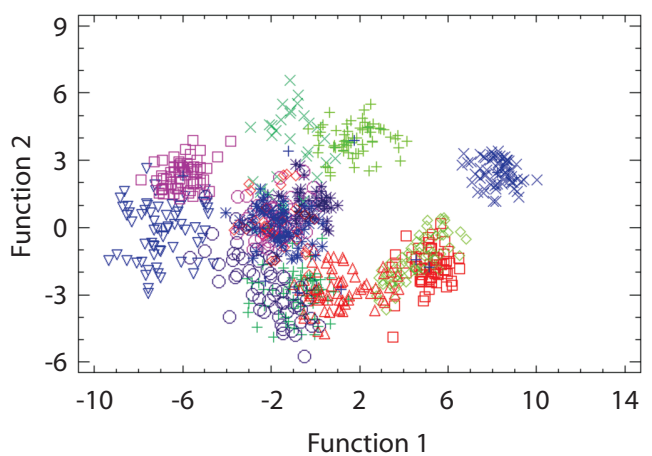

$\begin{array}{ll}\square & \text { B.brasiliense } \\
\times \quad \text { B.serrulatum } \\
\times \quad \text { B.tabulare } \\
+\quad \text { B.hastatum } \\
* \quad \text { B. magellacicum } \\
\triangle \quad \text { B.penna-marina } \\
\triangle \quad \text { B.sprucei }\end{array}$

B. mochaenum

B. stuebelii

B. fragile

B. kunthianum

B. loxense

B. columbiense

B. auratum

Centroids

Fig. 5. Discriminant analysis 2-D scatter plot. 
following variables: altitude, stomatal index, stomatal length and stomatal width. The results indicated that the cumulative percentage of variability of the two extracted components reached $83.76 \%$ of the variability of the data. Using component weights a 2D components plot (Fig. 6A) was obtained. One point appeared on the plot for each one of the four variables in the analysis. The samples as well as variables were represented both (Fig. 6B) in a 2D biplot. The plot described graphically the pattern of relative variation of data by projection onto a plane given by the first and second principal components. Considering the angles between line variables, the line variables lengths and sample clustering, we conclude that stomatal index was not correlated with altitude, stomatal length or width. The stomatal width was not correlated with altitude, whereas stomatal length exhibited a low correlation with altitude. However, stomata length and width were both correlated.

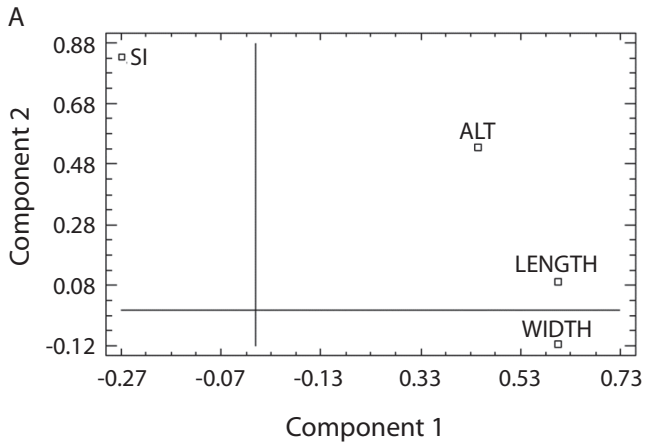

B

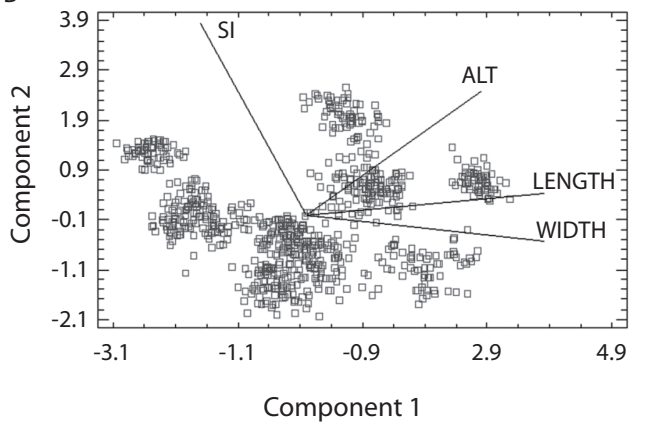

Fig. 6. Principal component analysis 2-D plot (A) and 2D biplot (B).

\section{DISCUSSION}

Variation in stomatal traits in Blechnum: Metcalfe \& Chalk (1979) affirmed that size of stomata is less influenced by exogenous factors than size of ordinary epidermal cells and, thus, than the stomatal density. The dermatogen matures rapidly to produce the epidermis, which reaches its adult stage earlier than other tissues (Wardlaw 1968), a condition that must also be taken into account. Both concepts could explain the observed fact that a constant linear correlation exists between stomatal length and width in Blechnum. This could also mean that stomatal size is genetically fixed at a specific level, over a more or less broad range of variation between pinna areas, pinnae, fronds and individuals. According to previous studies on different genera of the Pteridophyta, stomatal size exhibits a very low variability: Rolleri (1977) first mentioned this fact in Huperzia saurura; Rolleri et al. (2003) and Rolleri (2004) achieved same results in all genera of the Order Marattiales; similar conclusions were obtained by Prada et al. (2008) for Blechnum cordatum, after studying specimens from all its geographical distribution and altitudinal range. Analysis of species of every genus allowed measuring a large sample and these authors considered that size of stomata can be considered a specific trait, yet their range of variation can be considered a generic one. Furthermore, this genetically constant relationship between stomatal length and width derives also in the maintenance of a specifically fixed stomatal form. All these ideas are also supported by the additional known fact that stomatal size (like sizes of various other structures, as spores or epidermal cells) could change with ploidy (Stebbins 1950). Our results of the principal components analysis also suggest a similar explanation, in which endogenously controlled variables (length and width) are strongly related and can explain c. $84 \%$ of the variability of data. The discussed genetic meaning of stomatal size and form could lead to the consideration that these characters have taxonomic or diagnostic significance, as it 
has been early proposed by Metcalfe \& Chalk (1979) and others.

In regard with the stomatal frequency, we found that a linear inverse correlation exists between length and stomatal index, and also between width and stomatal index. The relationship is weak, as it can explain only the $5 \%$ and the $14 \%$, respectively, of the stomatal index variation. That could be explained by the mathematical fact that the index is calculated to make frequency independent of cell sizes. Thus, considering a genetically fixed size of stomata, and an individual need of fronds to acclimate to changing/new environments, we can suggest that the way of modifying water relations in Blechnum could be through the control of epidermal cell size, as it has been said for angiosperms, since Salisbury (1927).

Kessler et al. (2007) found that stomatal density varied much more strongly within than between species. These results could be influenced by the environment, as stomatal density is affected by the size of epidermal cells (i.e. by the spacing of stomata), a trait that plants modify to adapt their hydric economy to different environments (Salisbury 1927). However, when using the stomatal index, thus minimizing the effect of the environment in the results, our observations could suggest that the stomatal index varied more strongly between species than within any of them (Fig. 4A). Even using stomatal density, some authors have previously reported a more strong variation between species, as the case of Huperzia saurura (Rolleri 1977) and B. cordatum (Prada et al. 2008).

Anomalous behavior in ontogenetic sequence to adult stomata was taken into consideration. The stomata not completely formed, in which the mother cell of guard cells develops as a small epidermal cell instead of a normal pair of mature guard cells, detected in B. brasiliense, represented ca. $20 \%$ of the total stomata in some observation fields, which resulted in a proportional reduction in the stomatal frequency. This particular ontogenetic behavior could be explained either because of the influence of endogenous factors, as, for example, control of stomatal frequency, or exogenous, like environmental changes in soil nutrients and water availability, among others.

Much has been said about relationships between changes in stomatal frequency and altitude. The increase in altitude above sea level implies increasing reductions in $\mathrm{CO}_{2}$ levels, atmospheric vapour pressure and temperature, all factors affecting both photosynthetic efficiency and transpiration rate. Stomatal size and number usually modify to adapt individuals to optimize balance between $\mathrm{CO}_{2}$ uptake and water loss (Jones 1998). In general, there is a great consensus to accept that stomatal frequency of plants shows an inverse relation with $\mathrm{CO}_{2}$ concentration, so a direct relation with the altitude (Woodward \& Bazzaz 1988, Öpik \& Rolfe 2005), including ferns (Kessler et al. 2007, Kluge \& Kessler 2007). In spite of this, there are some remarkable species adapted to live at a certain height above sea level, with a very ample altitudinal range (for example, ranging from 2000 to $4000 \mathrm{~m}$ ), that do not show a remarkable variation in stomatal frequency (Rolleri 1977).

During the course of this study, relationships between stomatal traits and altitude in some species have been analysed, although this was not a primary objective analized. For two of our species we had stomatal information recorded at altitudes separated at least 500 meters: $B$. brasiliense (STOINDEX= $\left.28.186+0.008 \mathrm{ALT}, \mathrm{R}^{2}=35.458 ; p=0.000\right)$ and B. spruce; (STOINDEX $=10.208+0.007 \mathrm{ALT}$, $\left.\mathrm{R}^{2}=23.566 ; p=0.000\right)$. It is interesting to note that, in both cases, a $p$-value equal to zero shows that there is a statistically significant relationship between the altitude and the stomatal index. These preliminary results with $B$. spruce $i$ and $B$. brasiliense support the idea of a relationship between stomatal frequency and altitude in ferns, also proved with the genus Elaphoglossum (Kluge \& Kessler 2007). New samplings of Blechnum species along altitudinal gradients will help us to better understand this ecological feature in ferns. We could also try to probe the hypothesis that, as the stomatal index is less influenced by the habitat than the stomatal density, the former should be a better 
instrument to evaluate the influence of altitude in fern stomata.

As a general conclusion about the study of the biometrical variability of stomata, we can state that the size is a useful diagnostic tool due to its low dependence on external factors, while the frequency is a character that is or may be influenced by these factors. The results of the principal component analysis suggest that first component has an endogenous meaning (stomata length and width have higher weights than the two other variables) whereas the second component should be the explanation of the role of environment (stomatal index and altitude have the highest weights) on species. The diagnostic utility of stomatal size has been previously reported, but the statistical analyses that were carried out in this work add to the credibility of these comparative or empirical evaluations. There are few studies in ferns in which stomatal size appears analyzed as a single trait; rather, it is always included among several epidermal characters that work together, a fact that adds to the diagnostic value that stomatal size has as an isolated feature.

Relationships between stomatal traits and habit, habitat and ecosystem: Natural selection favors those individuals that facultatively adjust their phenotypes to the conditions in which they live (Stearns 1992). Ultimately, the importance of all factors that are able to maintain heritable genetic variation will depend upon the relative importance of the trait to adjustment. Less variance should be adapting traits that are more closely linked to fitness, and therefore subject of a higher intensity of stabilizing selection (Turelli 1984). Similarly, it is possible to compare the amplitude of measured variance of one trait in different ecological environments to decide in which of them the trait shows a higher adaptation.

The shortest stomata appear to be responding to a swamp ecosystem and an amphibious habitat, as in both circumstances the stomatal length showed the less variance and the lowest mean value. This feature should be explained in conjunction with the occurrence of the highest values of stomatal frequency, as is observed in Blechnum amphibious species of swamps. The need to eliminate the water excess could lead to the need of raising the stomata proportion. One way of achieving such a character is developing smaller cells, both in the epidermis and guard cells of stomata.

The broadest stomata appear to be responding to an epiphytic habit in Blechnum, as in this habit the stomatal width showed the less variance and the highest mean value. This fact could be explained by the xeric essential condition of the epiphytic life, with shallow or no soil at all and little available light, depending on canopy, and the consequent need of a high regulation of the hydric economy by moderating the loss of water. In the same sense, epiphytic species should reduce the stomatal frequency; our results with epiphytic Blechnum species support this idea, as they showed the lowest stomatal index values.

The lowest frequency of stomata appears to be responding to a tropical rainforest ecosystem, since plants from this habitat showed less variance and the lowest mean value. Blechnum species living in this particular environment have terrestrial or epiphytic habit. Each habit has a specific problem, closely related to a kind of environment in which space is occupied by too many plants and compete for any available resources (Capon 1994). Canopy diminishes the light that terrestrial plants receive and their soils are poor in nutrients; epiphytes compete successfully spending their lives over trees, near sun light, but loose soil nutrients and water. Thus, in both types of life forms it is expected the presence of the lowest values of stomatal frequency.

Small, in both in length and width, stomata with the lowest variance and also lowest mean values appear to be a response of the herbaceous habit, as these traits showed the less variance together with the lowest mean values. Comparatively, caespitose and arborescent species present bigger stomata due to a better access to water resources: caespitose Blechnum species are small cryophytes that live in wetlands o peatlands, usually at high latitudes, 
while arborescent species appear typically in swamps and paramos near to or directly on humid to flooded soils.

In regard with the ecological aspects, we can conclude that the morphological traits of stomata analyzed in this study (length, width and frequency) can be successfully used to explain the fitness of ferns to their environments. Consequently, we consider that it is necessary to include the analysis of the stomata morphology in every model that pretends to explain the auto-ecology of ferns.

\section{AKNOWLEDGMENTS}

The authors thank the financial support from the Agencia Española de Cooperación Internacional (Project A 8930/07), the Red Universitaria de Investigación sobre Cooperación para el Desarrollo (Project G07/10), the Programa de Creación y Consolidación de Grupos de Investigación, Universidad ComplutenseComunidad de Madrid, and the Programa de Becas Complutense-del Amo. Research was also supported by Universidad Nacional de La Plata and Consejo Nacional de Investigaciones Científicas y Técnicas de la República Argentina (CONICET).

\section{RESUMEN}

Los caracteres morfológicos estomáticos, tales como tamaño, forma y frecuencia, han sido objeto de abundante investigación, incluyendo su relación con los factores ambientales. Sin embargo, poco esfuerzo se ha realizado en esta materia en helechos y menos todavía en el género Blechnum. En este trabajo se midieron la longitud, anchura y frecuencia (como índice estomático) de estomas de pinnas adultas de un número de individuos en catorce especies de Blechnum neotropicales. El objetivo fue encontrar relaciones biométricas entre los caracteres estomáticos, y entre los caracteres estomáticos y el hábito, hábitat y ecosistema de las plantas. Se realizaron análisis estadísticos como Análisis Exploratorios de Datos y Métodos Estadísticos Multivariantes. La longitud y la anchura de los estomas mostraron una muy fuerte correlación, sugiriendo un control genético endógeno que otorga a estos caracteres un considerable valor diagnóstico. Con respecto a las relaciones entre los caracteres estomáticos y el ambiente, encontramos una relación estadísticamente significativa entre la altitud y el índice estomático. También se incluyen interpretaciones de la significación ecológico-selectiva de un conjunto de caracteres estomáticos en diferentes conjuntos de hábitos, hábitats y ecosistemas.

Palabras clave: Blechnum, helechos, autoecología, selección, frecuencia estomática, tamaño estomático.

\section{REFERENCES}

Baranova M.A. 1987. Historical development of the present classification of morphological types of stomata. Bot. Rev. 53: 53-79.

Bergmann D.C. 2003. Integrating signals in stomatal development. Curr. Opin. Plant Biol. 7: 1-7.

Capon B. 1994. Plant survival. Adapting to a hostile world. Timber, Portland, Oregon, USA.

Doi M., M. Wada \& K. Shimazaki. 2006. The fern Adiantum capillus-veneris lacks stomatal responses to blue light. Plant Cell Physiol. 47: 748-755.

Evert R.F. \& S.E. Eichhorn. 2006. Esau's Plant Anatomy. Wiley, New York, USA.

Franks P.J. \& G.D. Farquhar. 2007. The mechanical diversity of stomata and its significance in gas-exchange control. Plant Physiology 143: 78-87.

Fryns-Claessens E. \& W. Van Cotthem 1973. A new classification of the ontogenetic type of stomata. Bot. Rev. 39: 71-137.

Gabriel y Galán J.M., L.M. Passarelli, C. Prada \& C.H. Rolleri. 2008. Sporophyte morphology and gametophyte development of the fern Blechnum sprucei (Blechnaceae-Pteridophyta). Rev. Biol. Trop. 56: 2027-2040.

Gabriel y Galán, J.M., C. Prada, C.H. Rolleri, R. Lahoz Beltrá \& C. Martínez Calvo. 2010. A biometrical survey on Blechnum stomata (january 2010, http:// linneo.bio.ucm.es/criptogamas/GRUPO/paginas/Blechnum data.pdf)

Gurr L. 1966. The rational use of dyes in biology and general staining methods. Williams and Wilkins, Baltimore, USA.

Haberlandt G. 1965. Physiological plant anatomy. Today \& Tomorrow's, New Delhi, India.

Hetherington A.M. \& F.I. Woodward. 2003. The role of stomata in sensing and driving environmental change. Nature 424: 901-908. 
Hunt M.A., N.J. Davidson, G.L. Unwin \& D.C. Close. 2002. Ecophysiology of the Soft Tree Fern, Dicksonia antarctica Labill. Austral Ecol. 274: 360-368.

Inamdar J.A., R.C. Patel \& D.C. Bhatt. 1971. Structure and development of stomata in some leptosporangiate ferns. Ann. Bot. 35: 643-651.

Jones H.G. 1998. Stomatal control of photosynthesis and respiration. J. Exp. Bot. 49: 387-398.

Kawai H., T. Kanegae, S. Christensen, T. Kiyosue, Y. Sato, T. Imaizumi, A. Kadota \& M. Wada. 2003. Responses of ferns to red light are mediated by unconventional photoreceptor. Nature 421: 287-290.

Kessler M., Y. Siorak, M. Wunderlich \& C. Wegner. 2007. Patterns of morphological leaf traits among pteridophytes along humidity and temperature gradients in the Bolivian Andes. Funct. Plant Biol. 3411: 963-971.

Kluge J. \& M. Kessler. 2007. Morphological charactersitics of fern assemblages along an elevational gradient, patterns and causes. Ecotropica 13: 27-43.

Kondo T. \& H. Toda. 1956. A contribution to the study of fern stomata (I), with special references to their development and structure. Bull. Educ., Shizuoka Univ., Natural Science Series 5: 60-80.

Körner C. 1988. Does global increase of $\mathrm{CO}_{2}$ alter stomatal density? Flora 181: 253-257.

Kramer K.U., T.C. Chambers \& E. Hennipman. 1990. Blechnaceae, p. 60-67. In K. Kramer \& P.S. Green (eds.). The families and genera of vascular plants. 1 . Pteridophytes and Gymnosperms. Springer, Berlin, Germany.

Lellinger D. 2002. A modern multilingual glossary for taxonomic pteridology. Pteridologia 3: 1-263.

Meidner H. \& T.A. Mansfield. 1968. Physiology of stomata. McGraw-Hill, London, UK.

Metcalfe C.R. \& L. Chalk. 1979. Anatomy of the Dicotyledons, vol I. Clarendon, Oxford, UK.

Mickel J.T. \& A.R. Smith. 2004. The Pteridophytes of Mexico. Memoirs of the New York Botanical Garden 88: $1-1054$.

Moran R.C. 1995. Blechnaceae, p. 325-333. In G. Davidse, M. Souza \& S. Knapp (eds.). Flora Mesoamericana I, Psilotaceae a Salviniaceae. Universidad Autónoma de México, Missouri Botanical Garden and The Natural History Museum, London, UK.
Oliveira Dittrich V.A. 2005. Estudos taxonômicos no gênero Blechnum L. (Pteridophyta-Blechnaceae. para as regiões Sudeste e Sul do Brasil. PhD. Universidad Estadual Paulista Julio de Mesquita Filho. Rio Claro, São Paulo.

Öpik H \& S.A. Rolfe. 2005. The physiology of flowering plants. Cambrige University. Cambridge. UK.

Ponce M.M. 1996. Pteridophyta. In F. Zuloaga O, Morrone O (eds.), Catálogo de las plantas vasculares de la República Argentina, I. Pteridophyta, Gymnospermae y Angiospermae (Monocotyledoneae). Monographs in Systematic Botany from the Missouri Botanical Garden 60: 1-79. Missouri, USA.

Prabhakar M. 2003. Structure, delimitation, nomenclature and classification of stomata. Acta Bot. Sin. 462: 242-252.

Prada C., C.H. Rolleri \& L.M. Passarelli. 2008. Morfología, caracterización y distribución geográfica de Blechnum cordatum (Blechnaceae-Pteridophyta). Acta Bot. Malacit. 33: 29-46.

Rencher C.A. 1995. Methods of Multivariate Analysis. John Wiley and Sons, New York, USA.

Rodríguez R. 1995. Pteridophyta, p. 119-309. In C. Marticorena \& R. Rodríguez (eds.). Flora de Chile, Pteridophyta- Gymnospermae, 1. Universidad de Concepción, Chile.

Rolleri C.H. 1977. Correlation of Morphology and Geographical Distribution in Lycopodium saururus Lam. Am. Fern J. 67: 109-120.

Rolleri C.H. 2004. Revisión del género Danaea (Marattiaceae-Pteridophyta). Darwiniana 42: 217-301.

Rolleri C.H, A.M. Deferrari \& M.C. Ciciarelli. 1987. Epidermis y estomatogénesis en Marattiaceae. Revista del Museo de La Plata, n. s., Botánica, 14: 129-147.

Rolleri C.H, A.M. Deferrarri \& M.C. Lavalle. 1994. Epidermis y estomas porociclocíticos en Christensenia cumingiana Christ (Marattiales). Revista del Museo de La Plata, n.s., Botánica 14: 207-219.

Rolleri C.H. \& M.C. Lavalle. 1997. Análisis con MO y MEB de caracteres epidérmicos foliares en Marattiaceae. Revista del Museo de La Plata, n. s., Botánica 14: 433-453.

Rolleri C.H, A.M. Lavalle, A. Mengascini \& M. Rodríguez. 2003. Sistemática de los helechos eusporangiados (Marattiaceae-Marattiales). Revista del Museo de la Plata, n. s., Botánica 16: 49-64. 
Rolleri C.H. \& C. Prada. 2006a. Catálogo comentado de las especies de Blechnum (Blechnaceae-Pteridophyta. de Mesoamérica y Sudamérica. Anales Jard. Bot. Madrid 63: 67-106.

Rolleri C.H. \& C. Prada. 2006b. Revisión de los grupos de especies del género Blechnum (BlechnaceaePteridophyta), el grupo B. penna-marina. Acta Bot. Malacit. 31: 7-50.

Rolleri C.H., C. Prada \& L.M. Passarelli. 2008. Estudios morfológicos y taxonómicos en Blechnum (Blechnaceae-Pteridophyta), Blechnum tabulare y B. magellanicum. Anales Jard. Bot. Madrid. 65: 179-195.

Salas J.A., M.E. Sanabria \& R. Pire. 2001. Variación en el índice y densidad estomática en plantas de tomate (Lycopersicon esculentum Mill.) sometidas a tratamientos salinos. Bioagro 13: 99-104.

Saldaña A., E. Gianoli \& C.H. Lusk. 2005. Ecophysiological responses to light availability in three Blechnum species (Pteridophyta, Blechnaceae) of different ecological breadth. Oecologia 145: 252-257.

Salisbury E.J. 1927. On the causes and ecological significance of stomatal frequency, with special reference to the woodland flora. Philosophical Transactions of the Royal Society of London, B, 216: 1-65.

Sculthorpe C.D. 1971. The biology of aquatic vascular plants. Edward Arnold. London.

Smith A.R. 1995. Blechnaceae, p. 23-29. In P.A. Berry, B.K. Holst \& K. Yatskievych (eds.). Flora of the Venezuelan Guayana 2, Pteridophytes and Spermatophytes. Missouri Botanical Garden/Timber, St. Louis, USA.

Stearns S.C. 1992. The evolution of life histories. Oxford University, Oxford, UK.
Stebbins G.L. 1950. Variation and evolution in plants. Columbia University, New York, USA.

Thurston E.L. 1969. Taxonomic significance of stomatal patterns in the ferns. Am. Fern J. 59: 68-79.

Tryon R.M. \& R.G. Stolze. 1993. Pteridophyta of Peru. 5. Aspleniaceae-Polypodiaceae. Fieldiana, Botany New Series 32: 54-68.

Tryon R.M. \& A.F. Tryon. 1982. Ferns and allied plants, with special reference to tropical America. Springer. New York, USA.

Tukey J.W. 1977. Exploratory Data Analysis. AddisonWesley. Reading, Massachussetts, USA.

Turelli M. 1984. Heritable genetic variation via mutationselection balance, Lerch's zeta meets the abdominal bristle. Theor. Popul. Biol. 25: 138-193.

van Cotthem W. 1973. Stomatal types and systematics. In Jermy A.C., Crabble J.A., Thomas B.A. (Eds.). The Phylogeny and Classification of the Ferns. Supplement No. 1. Bot. J. Linn. Soc. 67: 59-71.

Wardlaw C.W. 1968. Morphogenesis in plants. A contemporary study. Methuen, London, UK.

Watkins J.E., P.W. Rundel \& C.L. Cardelús. 2007a. The influence of life form on carbon and nitrogen relationships in tropical rainforest ferns. Oecologia 153: 225-232.

Watkins J.E., M.C. Mack, T.R. Sinclair \& S.S. Mulkey. 2007b. Ecological and evolutionary consequences of desiccation tolerance in tropical fern gametophytes. New Phytol. 176: 708-717.

Woodward F.I. \& F.A. Bazzaz. 1988. The response of stomatal density to $\mathrm{CO}_{2}$ partial pressure. J. Exp. Bot. 39: 1771-1781. 